\title{
水・物質循環と河川の流域環境
}

\author{
小倉 紀雄* \\ Water and Material Circulation and Watershed Environment of the River

\section{Norio OGURA*}

\begin{abstract}
Water and material circulations and human activities at the river basin were discussed, and countermeasures to conserve and rehabilitate fine and comfortable aquatic environments were proposed. At a river basin, conservation of forest, farm-land and other permeable lands, development of sewage systems and measures against household effluents are considered to be important countermeasures. In the river, it is important to rehabilitate natural-type river, to intensify selfpurification capacity. Environmental conservation movements by citizens are also important and cooperation of administration and citizens is necessary for establishment of consultation and agreement.
\end{abstract}

Key words : Water cycle, material cycle, river basin, human activities, conservation and restoration of environment, environmental science for citizen

キーワード : 水循環、物質循環、河川流域、人間活動、環境の保全・修復、市民 環境科学

\section{I.はじめに}

生物圈に豊富に存在する水は、生物圈を温和な 気候に保ち、生物の生存を可能にしている。水圈 のなかで、河川はさまざまな物質を上流から下流 へ運搬する場であるとともに、有機物の分解や硝 化・脱窒など物質の形態変化のおこる場でもある。 また河川は治水上、安全で、豊富な水量をもち生 物が生息でき、川辺に人が近づきやすい場である ことが望ましい。

地球温暖化、熱帯林の伐採など人間活動の影響 により地球規模での水循環のバランスが崩れ、世 界各地で洪水が扔こり、一方では乾燥化・砂漠化 する地域も増加している。また、地域での水循環 のバランスも崩壞し、各地で河川の汇濫や少雨に よる河川の枯渴、また水質の污染などさまざまな
問題がおこっている。

環境基本法に基づき、環境基本計画が1994年 12 月に制定され、その長期的な目標として次の 4 つ の目標が掲げられた：「循環を基調とする経済シ ステムの実現」、自然と人間の共生の確保」、「環 境保全に関する行動への参加」、「国際的な取組み の推進」。

1995年3月、河川審議会は「今後の河川環境の あり方について」を答申し、「健全な水循環系の 確保」、生物の多様な生息・生育環境の確保」、 「河川と地域の関係の再構築」を目標に掲げ流域 全体を対象とした総合的な取り組みを求めた。

このように、快適な水環境を保全し、とりもど すためにさまざまな試みが各地で行われるように なった。水や物質循環を流域全体、さらに流域を 越えて広域的に考え、バランスのとれた社会シス

* 東京農工大学農学部 (Faculty of Agriculture, Tokyo University of Agriculture \& Technology) 
テムを構築することの重要性が認識されるように なった。本シンポジウムでは、河川の流域環境を 例にし、水・物質循環と人間活動の影響およびこ れら循環の修復の方策と専門家の役割について述 ベてみたい。

\section{II. 水循㻴と人間活動}

水循環と人間活動について具体的な例（森林伐 採、水田・農地の減少、都市化）と安全で豊かな 水量をもつ河川を保全・創出するための方法につ いて述べてみよう。

\section{1. 森林伐採}

森林は水循環をコントロールする重要な役割を 果たしている。その大きな要因は団粒構造をつく り、保水能力の大きな森林土壤の存在である。森 林が伐採され荒廃した山地では、土壤の保水能力 が低下し、大雨が降れば急激な流出が起こるが、 平常時の河川流量は減少する。また、米国東部の Hubbard Brook実験林での水質変化を見ると、 森林の伐採により数か月後から硝酸態窒素やカル シウム、カリウムなどの濃度が急激に増加し、下 流域の富栄養化をもたらした (Likensら、1970)。 しかし伐採されないコントロール流域での水質変 化は認められず、森林は水量だけでなく、水質も コントロールする重要な役割を担っていることが わかる。

また上流の森林が伐採されると、山地から流出 した土砂は下流へ運ばれ沿岸域に堆積し、魚介類 の生産量は減少した。そこで伐採された森林に植 林を行うと、緑化面積の増加に伴ない漁獲高も回 復することが認められている（東、1992）。この ように一つの河川について、森から海まで流域全 体で総合的な保全を考えることが重要である。

\section{2. 水田の減少}

水循環や水資源の維持確保のために水田の役割 は大きいと考えられる。志村 (1982) によると、 わが国の水田 (300万ha)の雨水貯留可能容量は81
Table 1 Land use and potential volume of water storage in Japan (Shimura, 1982).

\begin{tabular}{|c|c|c|c|}
\hline 土地利用 & 面積 万ha & 貯水可能量 億 $\mathrm{m}^{3}$ & $\%$ \\
\hline 森 林 & 2520 & 444 & 68 \\
\hline 水 田 & 300 & 81 & 13 \\
\hline 畑 & 240 & 14 & 2 \\
\hline 原 野 & 40 & 0.4 & 0.1 \\
\hline 採草放牧地 & 20 & 0.2 & - \\
\hline ダ ム & & 110 & 17 \\
\hline 国土面積 & 3250 & 650 & 100 \\
\hline
\end{tabular}

億トンであり、国土保全のために必要な貯水可能 容量の $13 \%$ に相当する（Table 1)。しかし1994年 現在、水田面積は276万haに減少し、都市の洪水 の原因の一つになっている。千葉県市川市では洪 水の防止の目的で、1986年に「水田等の遊水機能 保全対策要綱」をつくり、水田等の所有者と保全 協定を結び助成金を支払うことにした。現在、お よそ44haの水田が保全され、そのための費用は 2,200万円程度であり、大規模な遊水池を造成す ることに比べ経済的メリットは極めて大きいとい える。

\section{3. 都市化}

都市では宅地、舗装道路など不透水性面積の増 加により雨水の地下浸透量が減少し、地下水位の 低下や湧水量の減少や枯渴がおこっている。東京 都区部と多摩地域の被覆率と雨水浸透量の変化を

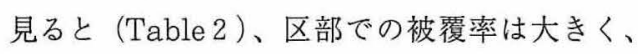
雨水浸透量は多摩地域の $1 / 3$ 程度である。また 1968年から1986年までの18年間に被覆率は増加し、 雨水浸透量は減少している（東京都環境保全局、 1992).

コンクリートやアスファルトで覆われた都市中 心地域の流出倸数は0.7 0.9と大きく、強い雨が 降ると表面流出した雨水は河川に急激に流入し、 中小河川の氾濫がしばしば起こっている。このよ うな都市型の洪水を防止するため、都市河川はコ ンクリート張り・直線的に改修され、水を下流に 素早く排除する水路になっている。しかし、雨の 
Table 2 Change in proportion of coverage and water budget in Tokyo (Bureau of Environmental Protection, Tokyo Metropolitan Government,1992).

\begin{tabular}{|c|c|c|c|c|c|}
\hline & \multicolumn{4}{|c|}{ 単位:千 $\mathrm{m}^{3} /$ 日 } \\
\hline & & \multicolumn{2}{|c|}{ 区 部 } & \multicolumn{2}{|c|}{ 多摩地域 } \\
\hline & & 1968 & 1986 & 1968 & 1986 \\
\hline \multicolumn{2}{|c|}{ 降 水 量 } & $\begin{array}{c}2,524 \\
(100 \%)\end{array}$ & $\begin{array}{c}2,355 \\
(100 \%)\end{array}$ & $\begin{array}{c}3,221 \\
(100 \%)\end{array}$ & $\begin{array}{c}2,967 \\
(100 \%)\end{array}$ \\
\hline \multirow[t]{2}{*}{ 内 } & 蒸発散量 & $\begin{array}{c}603 \\
(23.9 \%) \\
\end{array}$ & $\begin{array}{r}540 \\
(22.9 \%) \\
\end{array}$ & $\begin{array}{c}1,024 \\
(31.8 \%)\end{array}$ & $\begin{array}{r}855 \\
(28.8 \%) \\
\end{array}$ \\
\hline & 直接流出量 & $\begin{array}{c}1,524 \\
(60.4 \%) \\
\end{array}$ & $\begin{array}{c}1,525 \\
(64.8 \%) \\
\end{array}$ & $\begin{array}{r}735 \\
(22.8 \%) \\
\end{array}$ & $\begin{array}{r}1,165 \\
(39.3 \%) \\
\end{array}$ \\
\hline |訳 & 雨水浸透量 & $\begin{array}{c}397 \\
(15.7 \%)\end{array}$ & $\begin{array}{c}290 \\
(12.3 \%)\end{array}$ & $\begin{array}{c}1,462 \\
(45.4 \%)\end{array}$ & $\begin{array}{r}946 \\
(31.9 \%) \\
\end{array}$ \\
\hline
\end{tabular}

\begin{tabular}{|c|c|c|c|c|}
\hline \multirow{2}{*}{} & \multicolumn{2}{|c|}{ 区 } & \multicolumn{2}{c|}{ 多摩地域 } \\
\cline { 2 - 5 } & 1968 & 1986 & 1968 & 1986 \\
\hline 被覆率 & $73.9 \%$ & $79.3 \%$ & $29.6 \%$ & $49.0 \%$ \\
\hline
\end{tabular}

少ない年ゃ時期に、都市河川の水量は減少し、水 が無くなることもしばしばある。

都市の中に雨水が浸透しやすい緑地や農地を保 全し、また雨水を浸透させる設伯（雨水浸透ます など）を設置し、都市の水循環を回復させること が重要である。一軒の家に雨水浸透ますを 2 基設 置すると年間 $120 \mathrm{~m}^{3} 、 1$ 日 $328 \ell$ の雨水を地下に浸 透させることができる（東京都、1993）。しかし、 雨水浸透ますの設置により、湧水量が明らかに増 加した事例はあまり認められておらず、その効果 をより定量的に評価する必要がある。

\section{III. 物質循㻴と人間活動：流域における 污濁の発生源とその制御}

流域にはFig. 1に示すように、森林から海まで さまざまな場所に面源・点源の污濁発生源がある。 流域においてバランスのとれた物質循環を維持す るために、それぞれの発生源で污濁を削減し、流 域全体で污濁の制御を総合的に考えることが重要 である。

\section{1. 大気降下物}

かつて雨から供給される窒素は農作物の肥料源

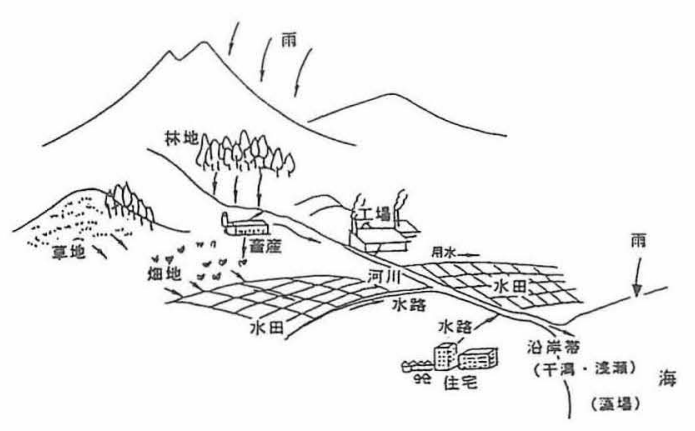

Fig. 1 Pollution source at the river basin.

として貴重なものであったが、現在では雨から供 給される空素酸化物、硫黄酸化物は過剰となり、 水域の富栄養化や酸性化の原因となっている。

\section{2. 森林・農地}

面的な污濁発生源として、森林や林地から排出 される窒素化合物がある。前述のように、森林を 伐採すると硝酸イオンやカルシウムイオンなどが 増加する。またスギ・ヒノキの植林面積比が増大 すると、河川水中の硝酸イオン濃度は増加し（江 角・古井戸、1981)、樹齢が高くなると硝酸イオ ンの流出が少なくなる（升方・小川、1982）こと が知られている。このように健全な森林、とくに 広葉樹林を保全し、育成することが流域の水循環 のバランスを保ち、水質を保全することにつなが る。

農地では過剩の肥料や農薬の使用をさけ、流出 負荷をできる限り少なくすることが重要である。

\section{3. 家庭・事業所}

下水道の整備や合併浄化槽の設置は水質の保全 に有効であるが、これらの未整備地域では、身近 にできる台所での雑排水対策が有効である。これ によりCOD，BODなどの負荷量の $20 ３ 0 \%$ が削 減される効果がある。例えば東京湾流域の住民の 2 割の人たちがこのような対策に協力すると、1 日に約 6トンのCODが削減される（藤原、1987）。 これは30 40万人の下水処理施設での処理効果に 匹敵する有効な対策となる。 


\section{4. 側溝・水路}

側溝・水路では、例えば木炭を利用した水質浄 化が考えられる。東京都八王子市の「浅川地区環 境を守る婦人の会」により南浅川の側溝において 始められた木炭による水質浄化の試み（加藤、 1988）は大きな反響を呼び、様々な地域に広がっ た。木炭による水質浄化の効果は使用する木炭の 量および水路の水質と水量に影響されるので（新 船ら、1991）、家庭など污濁発生源からの負荷量 をできる限り削減することが木炭浄化に有効であ る。

\section{5. 河川}

河川は本来、自浄作用をもっているが、洪水対 策のために都市河川はコンクリート張りに改修さ れ、自浄作用が有効に機能していないところが多 い。しかし、最近、このような考えが見直され、 多自然型の川づくりなど自净作用を強化するよう な対策が積極的に取り入れられている（楠田、19 94）。磔間接触酸化法や沿岸域における大型抽水 植物（ヨシ）を用いた浄化対策が実施され、水質 净化の効果が認められている。

自然型の川への改修による水質浄化の効果につ いての定量的な解析はほとんど行われていないが、 野川においてコンクリート河床と自然河床での脱 窒活性の比較した研究がある（吳ら、1992）。そ の結果によると両河床の区間当たりの脱窒活性と 河川水の流達時間から求めた窒素負荷量に対する 脱窒量の割合は、コンクリート河床区間で平均 $0.3 \%$ であったのに対し、磞などからなる自然河 床区間では平均 $2.3 \%$ と大きかったここのように 磁などからなる自然河床区間の方が水がゆっくり 流れ、浄化が有効に作用すると考えられる。

\section{6. 干潟・沿岸域}

干潟には多様な生物が生息し、有機物の分解・ 脱窒作用などが活発におこっている。しかし、都 市周辺の干潟や浅瀬の埋め立てが進み、東京湾で は、かって136 km² あった干潟は1980年頃には およそ $10 \mathrm{~km}^{2}$ にまで減少した（環境庁水質保全
局、1990)。現在の東京湾の干潟・浅瀬における 脱窒素の量は約10～18トン／日で、湾への流入負 荷量の3〜6\%に相当する（小倉、1993）。また干 潟に生息する東京湾干潟のアサリによる懸濁有機 物の取り込み量は約20トン／日で、流入負荷の約 7\%に相当する（向井、1993）。このように干潟や 浅瀬は水質浄化に大きな役割を果たしていると考 えられる。しかし、干潟や浅瀬の減少が、東京湾 の自浄作用を低下させ、水質の改善を䐅らせてい る原因の一つになっている。

干潟は水質浄化の場であるばかりでなく、レク レーションや水鳥の生息の場でもある。またそこ は文化的、社会的、経済的な価值をもつ優れたオー プンスペースであり、干潟の保全と再生は流域に おける物質循環のバランスを保つ面からも重要で ある。

\section{N 、 今後の河川環境のあり方}

\section{1. 今後の河川環境のあり方と新しい総合研究の 展開}

河川において水や物質の循環のバランスを維持 するために、生物と生息環境とヒトとの共生が大 切であろう。このような河川のあり方を明らかに するために、建設省の補助金により河川工学と河 川生態学・物質循環学とを結びつけた『河川生態 学術研究会』が発足し、新しい総合研究が1996年 より行われている。

研究会のおもな目的は次の通りである：

(1)流域の土地利用の変化や河川の改修に伴なう河 川の自然の変化と応答を解明する。

(2)河川の生物の生態や生息場所との関連を明らか にする。

(3)河川の物質や生物の現存量やエネルギーの流れ を調査し、河川生態系のメカニズムを明らかに する。

(4)多自然型川づくりなど河川の再自然化の効果を 実証する。

現在、多摩川と干曲川をモデル河川として総合 的な調査研究が行われており、河川についての新 
しい知見が期待される。

古代文明は河川流域を中心として発展したよう に、川の流域にはヒトが住み、特有な文化が発展 した。しかし、伝統的に引き継がれてきた文化は 人間活動の増大や生活様式の変化に伴ない失われ つつあるので、これらを生かした河川環境の保全 と管理も大切であろう。

減少している都市河川の基底流量を安定に保つ ために、緑地 (浸透性) 面積と流出係数の関係を 定量的に表現し、開発の際に確保すべき適切な緑 地面積を評価する手法（自然のもつ環境容量）を 確立する必要がある。

\section{2. 市民環境科学の発展と支援}

河川などの水質污染の主な原因は生活排水によ ると考えられ、その対策が重要な課題となってい る。そのため、多くの市民が水の污れに関心を持 ち、実態を知り、適切な対策を講ずることが求め られている。

最近、水質の簡易測定法が普及し (小倉、1987)、 市民による水質測定が各地で行われ、そのネット ワークが広がってきた（小倉,1994)。また、前述 の「婦人の会」により始められた木炭による水質 净化も多くの市民グループや行政に広がった。市 民が自ら水質を測定し、結果の意義を読みとり、 それを評価するようになったことは、市民運動の 質とレベルを飛躍的に向上させた。市民環境科学 の誕生である (小倉、1992)。水質測定のネット ワークが広がった理由は、市民の熱意と専門家に よる適切な指導であったが、簡易測定法の普及に 貢献したメーカーの役割も大きい。

このような試みは市民自ら水の污れの実態と原 因を知り、水質污染の削減対策を考えるきっかけ となり、環境教育・学習としても大きな意義を持っ ている。現在まで得られている調査研究の成果を わかりやすい言葉に翻訳し、今後も市民環境科学 を支援したい。

\section{3. 水環境の保全・修復とそのための仕組み}

身近な水環境を保全・修復するために、地域住
Table 3 Three principles and seven rules for agreement (Society for the Study on Conservation of Spring Water and Cliff, 1993).

\begin{tabular}{|c|c|}
\hline 3つの原則 & 7つのルール \\
\hline I 自由な発言 & $\begin{array}{l}\text { 1. 参加者の見解は、所属団体の } \\
\text { 公的見解としない } \\
\text { 2. 特定個人・団体のつるしあげは } \\
\text { 行なわない }\end{array}$ \\
\hline II 徹底した議論 & $\begin{array}{l}\text { 3. 議論はフェアプレイの精神で行 } \\
\text { なう } \\
\text { 4. 議論を進めるに当たっては、実 } \\
\text { 証的なデー夕を尊重する }\end{array}$ \\
\hline III 合意の形成 & $\begin{array}{l}\text { 5. 問題の所在を明確にしたうえで, } \\
\text { 合意をめざす } \\
\text { 6. 現在係争中の問題は、客観的な } \\
\text { 立場で事例として取り扱う } \\
\text { 7. プログラムづくりに当たっては、 } \\
\text { 長期的に取り扱うものおよび短 } \\
\text { 期的に取り組むものを区分し、 } \\
\text { 実現可能な提言をめざす。 }\end{array}$ \\
\hline
\end{tabular}

民と行政・事業者が同じテーブルで話し合うこと が大切である。1992年、東京多摩地域が神奈川県 から東京府へ移管され100周年を記念した事業 「TAMAらいふ21」が実施された。そのプログラ ムの一つに「湧水崖線の保全」があり、それを推 進するために「湧水崖線研究会」がつくられた。 研究会では市民と行政が同じテーブルについて、 多摩地域の水と緑を保全するための方法と仕組み が検討された。そのさい、「 3 つの原則・7つの ルール」(Table 3) がつくられ、実りある議論 の場をつくることが可能となった（湧水崖線研究 会、1993)。

水および物質循環のバランスのとれた社会シス テムを構筑するために、流域を一体とした取り組 みと住民の環境保全活動への積極的な参加が、い ま求められている。

本稿は1997年6月13日に開催された日本水文科 学会・日本地下水学会合同シンポジウム「水・物 質循環と環境」において発表した基調講演の内容 をとりまとめたものである。 


\section{文 献}

新船智子 - 石井保治・荻原弘次 - 小倉紀雄 (1991): 木炭による水質浄化実験とその評価. 用水と廃 水, 33, 993-1001.

江角比出郎・古井戸良雄（1981）: 栄養塩及び有 機物の動態に関する研究ー多摩川上流域の硝酸 態窒素. 環境科学研究報告書, B74-R12-4, 227234.

点 鐘敏 ·上田眞吾 - 小倉紀雄 (1992）: 自然浄 化機能としての野川における脱窒過程の役割. 水環境学会誌, 15, 909-917.

小倉紀雄（1987）：「調べる・身近な水」. 講談社, $166 \mathrm{p}$.

小倉紀雄（1992）:「きれいな水を取り戻すために一 市民環境科学の誕生」あすなろ書房, 197p.

小倉紀雄（編）（1993）:「東京湾－100年の環境変 遷」. 恒星社厚生閣, 193p.

小倉紀雄（1994）: 大学・社会における環境教育 と環境学習. 水環境学会誌, 17, 713-717.

加藤文江 (1988)：浅川周辺住民の手づくりの河 川浄化一木炭による浄化の実験から一. 水質污 濁研究，11，24-26.

環境庁水質保全局（1990）:「かけがえのない東京 湾を次世代に引き継ぐために」. 大蔵省印刷局, $70 \mathrm{p}$.

楠田哲也編著（1994）：「自然の浄化機構の強化と 制御」. 技報堂出版， $242 \mathrm{p}$.

志村博康（1982）：水田・畑の治水機能評価一国
土に必要な治水容量の農地・ダム・森林による 分担. 農業土木学会誌, 50, 25-29.

東京都環境保全局（1992）: 「地下水実態報告書」. 東京都環境保全局, 160p.

東京都 (1993) : 「東京都水辺環境保全計画」. 東 京都環境保全局, $177 \mathrm{p}$.

東 三郎 (1992)：「北海道 : 森と水の話」. 北海 道新聞社, $256 \mathrm{p}$.

藤原正弘（1987）：生活排水と水質保全. 用水と 廃水, 29, 5-10.

升方ひろみ・小川房人（1982）：河川の水質に対 する植生の影響一降雨にともなう流量, $\mathrm{NO}_{3}$ 濃度の変化. 環境科学研究報告書, B152-R128, 41-44.

向井 宏 (1993) : 「東京湾-100年の環境変遷」 (小倉紀雄編)。恒星社厚生閣, $193 \mathrm{p}$ 湧水崖線研究会 (1993) : 「湧水崖線研究会報告書」. TAMAらいふ21協会.

Likens,G.E., Bormann, F.H., Johnson, D.W., Fisher D.W., and Pierce,R.S. (1970): Effects of forest cutting and herbicide treatment on nutrient budgets in the Hubbard Brook watershed-ecosystem. Ecol. Monogr.,40, 23-47.

（受付 1997年 8 月18日）

(受理 1997年10月13日)

この論文に対する「討論」を1998年 5 月 31 日ま で受付けます。 